\title{
Onset of Significant GH Dependence of Serum IGF-I and IGF-Binding Protein 3 Concentrations in Early Life
}

\author{
L.C.K. LOW, S.Y.M. TAM, E.Y.W. KWAN, A.M.C. TSANG, AND J. KARLBERG \\ Department of Paediatrics [L.C.K.L., S.Y.M.T., E.Y.W.K., A.M.C.T., J.K.] and Clinical Trials Centre, \\ Faculty of Medicine [J.K.], The University of Hong Kong, Hong Kong SAR, PR China
}

ABSTRACT

\begin{abstract}
Forty-eight normal full-term Chinese babies (25 boys and 23 girls) were followed up every 2 mo in the first year and every 3 mo during the second year of life for anthropometric measurements. Blood samples were taken at birth and at 6,10, 12, and 18 mo after birth for serum GH-binding protein, IGF-I, and IGFbinding protein 3 analysis. Onset of the childhood phase of growth in the infants was determined from the growth data plotted on Infancy-Childhood-Puberty growth charts. The serum GH-binding protein concentrations were low in cord blood but rose significantly at $6 \mathrm{mo}$, with slower rises in late infancy and early childhood. However, a significant rise in serum IGF-I and IGF-binding protein 3 levels was only observed from 10 mo of life onward. The change in IGF-I between birth and 6 mo was significantly correlated with length gain $\left(r^{2}=0.35, p<0.05\right)$ and body mass index gain $\left(r^{2}=0.41, p<0.01\right)$ during the same period. The 34 infants with onset of childhood phase of growth between 6 and 10 mo had a higher mean serum IGF-I value at 10 mo $(8.8 \pm 5.8 \mathrm{nM}$ versus $4.9 \pm 3.1 \mathrm{nM} ; p<0.05)$ and higher length velocity between 10 and $12 \mathrm{mo}(16.3 \pm 4.7 \mathrm{~cm} / \mathrm{y}$ versus $8.8 \pm 4.3 \mathrm{~cm} / \mathrm{y} ; p<0.001)$ compared with the 14 infants with a later onset after 10 mo of age. A significant correlation between
\end{abstract}

a change in serum IGF-I and IGF-binding protein 3 levels was observed during the three 6-mo periods between birth and $18 \mathrm{mo}$, but a significant correlation between a change in serum GHbinding protein and a change in serum IGF-I or IGF-binding protein 3 levels was only seen between 12 and 18 mo of age. The multiple regression analysis $\left(r^{2}=0.43, p=0.0002\right)$ revealed that the change in serum GH-binding protein and IGF-I concentrations between 6 and 12 mo of age and the age of onset of childhood phase of growth could explain $43 \%$ of the length gain between 6 and 12 mo of age in our babies. The results of our study support the hypothesis that the onset of the childhood phase of growth is associated with the onset of significant $\mathrm{GH}$ action on growth. (Pediatr Res 50: 737-742, 2001)

Abbreviations
IGFBP-3, IGF-binding protein 3
GHBP, GH-binding protein
CV, coefficient of variation
BMI, body mass index
GHR, GH receptor

IGF-I synthesis in fetal tissues begins as early as 9-19 wk of gestation (6), and the dominant influence on fetal IGF levels at least in the second half of pregnancy seems to be the nutrient status, particularly the availability of glucose to the fetus and the consequent changes in fetal insulin release (7). In early postnatal life, nutrition, insulin, and IGF-I still regulate growth to a large extent.

In early infancy, circulating GH levels are high and serum IGF-I concentrations are low compared with later childhood and in adult life $(3,8-10)$. The hypersomatotropinemia in infancy may result from a lack of negative feedback from the relatively low concentrations of circulating IGF-I and low levels of GH receptors in tissues of infants, suggesting a degree of $\mathrm{GH}$ resistance (11-13). Postnatally the effects of $\mathrm{GH}$ on linear growth do not become prominent until late infancy. According to the Infancy-Childhood-Puberty growth model, human growth can be broken down into an infancy phase of
Received November 23, 2000; accepted May 7, 2001.

Correspondence and rprint requests: L.C.K. Low, M.B., F.R.C.P., Department of Paediatrics, The University of Hong Kong, Queen Mary Hospital, Pokfulam Road, Hong Kong SAR, PR China; e-mail: lcklow@hkucc.hku.hk

Supported by grants (337-045-0009 and 335-045-0019) from the Committee on Research and Conference Grant of the University of Hong Kong. 
growth, which is dependent on nutrition; a childhood phase of growth, which is dependent on hormones and growth factors (especially GH); and the pubertal phase of growth, during which both hormones and sex steroids have a significant effect (14). It has been suggested that the onset of the childhood phase of growth, which is characterized by an abrupt increase in length velocity occurring usually in the second 6 mo of life, marks the time when GH starts to have a significant effect on linear growth (14).

Although IGF-I is now well established to play an important role in postnatal growth (15-17), the timing of the onset of GH dependence of serum total IGF-I and IGFBP-3 concentrations has not been clearly delineated. The usefulness of obtaining serum IGF-I and IGFBP-3 concentrations in infancy for the investigation of infants with growth problems is limited because normal values for this age group have not been well established. Detailed studies of the changes in the serum GHBP, IGF-I, and IGFBP-3 in the first 2 y of life are limited $(3,10,12,13,16-25)$. We report here a longitudinal study of the serum GHBP, IGF-I, and IGFBP-3 concentrations in a group of normal Chinese babies in the first 18 mo of life and their correlations with growth during this period with a special reference to the onset of the childhood phase of growth.

\section{METHODS}

Forty-eight full-term Chinese babies ( 25 boys and 23 girls) with a birth weight between 2.7 and $4.0 \mathrm{~kg}$, born to mothers without preexisting illness or pregnancy complications, were recruited into the study. The babies were followed up every 2 mo in the first year and every 3 mo during the second year of life. At each follow-up visit, anthropometric measurements (supine length, weight and head circumference) were taken using standardized techniques by one investigator (S.Y.M.T.), together with a complete physical examination by a pediatrician. Blood samples were taken at birth and at $6,10,12$, and 18 mo after birth, and the serum samples were stored at $-70^{\circ} \mathrm{C}$ until analysis for GHBP, IGF-I, and IGFBP3. The study was approved by the Ethics Committee, Faculty of Medicine, The University of Hong Kong, and written informed consent was obtained from the parents.

GHBP was determined in duplicate by an MAb assay (Endocrine Sciences, Calabasas Hill, CA, U.S.A.) by incubating the serum samples with excess radiolabeled human GH and an $\mathrm{MAb}$. The intra- and interassay CVs were reported to be $5.6 \%$ and $9.5 \%$, respectively. Serum IGF-I and IGFBP-3 were measured by two-site immunoradiometric assays supplied by Diagnostic Systems Laboratories Inc. (Webster, TX, U.S.A.). For the IGF-I assay, the intra- and interassay CVs were $3.2 \%$ and $6 \%$ at the level of $7.8 \mathrm{nM}$ and $2.1 \%$ and $3.6 \%$ at the level of 26
$\mathrm{nM}$. For the IGFBP-3 assay, the intra- and interassay CVs were $2.6 \%$ and $6.3 \%$ at the level of $15.8 \mathrm{nM}$ and $3.6 \%$ and $6.9 \%$ at the level of $87.5 \mathrm{nM}$.

The age of onset of the childhood phase of growth was determined by visual inspection of the measured attained length and the change in growth velocity displayed on a computer-generated Infancy-Childhood-Puberty-based growth chart as previously described (26). Babies with the onset age occurring between 6 and 10 mo of age would be regarded as the early onset group whereas those with onset occurring after 10 mo of age were referred to as the late-onset group.

The results were expressed as the mean and SD. The mean serum IGF-I and IGFBP-3 levels between the early and lateonset groups of babies at different ages were compared using the Wilcoxon two-sample test. The correlation of the serum growth factors with various measures was explored using the bivariate correlation coefficient (Spearman) at different ages and age intervals. Multiple linear regression was used to analyze the effects of serum growth factors on body length with adjustment made for sex, age of onset of childhood phase, and energy intake.

\section{RESULTS}

The mean gestational age, birth weight, and birth length of the babies are shown in Table 1. The change in length during the first $2 \mathrm{y}$ of life in the babies did not deviate significantly from the National Center of Health Statistics growth reference, and this had been previously reported (27). The mean age of onset of the childhood phase of growth was 9.9 mo in boys and 9.6 mo in girls, which was not significantly different from that derived from a Swedish longitudinal growth study cohort (26). Only one boy and one girl had an onset of the childhood phase of growth after 12 mo of age.

The serum IGF-I levels were not normally distributed, and the antilogarithmic mean and its $95 \%$ confidence intervals of the serum IGF-I values from birth to 18 mo are shown in Figure 1. The serum GHBP, IGF-I, and IGFBP-3 concentrations between birth and 18 mo in the 48 infants are shown in Table 2 and Figures 2 and 3. Significant correlations between serum IGF-I and IGFBP-3 concentrations were demonstrated at birth $\left(r^{2}=0.59\right), 6 \mathrm{mo}\left(r^{2}=0.52\right), 12 \mathrm{mo}\left(r^{2}=0.61\right)$, and $18 \mathrm{mo}\left(r^{2}=0.68\right)$ of age $(p<0.01)$. At birth, neither serum GHBP, IGF-I, or IGFBP-3 concentrations were significantly correlated with birth length, birth weight, or BMI. The change in IGF-I between birth and 6 mo was significantly correlated with length gain $\left(r^{2}=0.35, p<0.05\right)$ and BMI gain $\left(r^{2}=\right.$ $0.41, p<0.01)$ during the same period. No significant corre-

Table 1. Gestational age, birth weight, and birth length of 48 healthy full-term Chinese infants

\begin{tabular}{|c|c|c|c|c|c|c|c|c|}
\hline Variable & \multicolumn{4}{|c|}{ Boys $(\mathrm{n}=25)$} & \multicolumn{4}{|c|}{ Girls $(\mathrm{n}=23)$} \\
\hline Gestational age (wk) & 39.2 & 1.10 & 37 & 42 & 39.3 & 1.10 & 37 & 42 \\
\hline Birth length (cm) & 50.2 & 1.35 & 47.1 & 53.2 & 49.8 & 1.30 & 47.5 & 53.8 \\
\hline
\end{tabular}




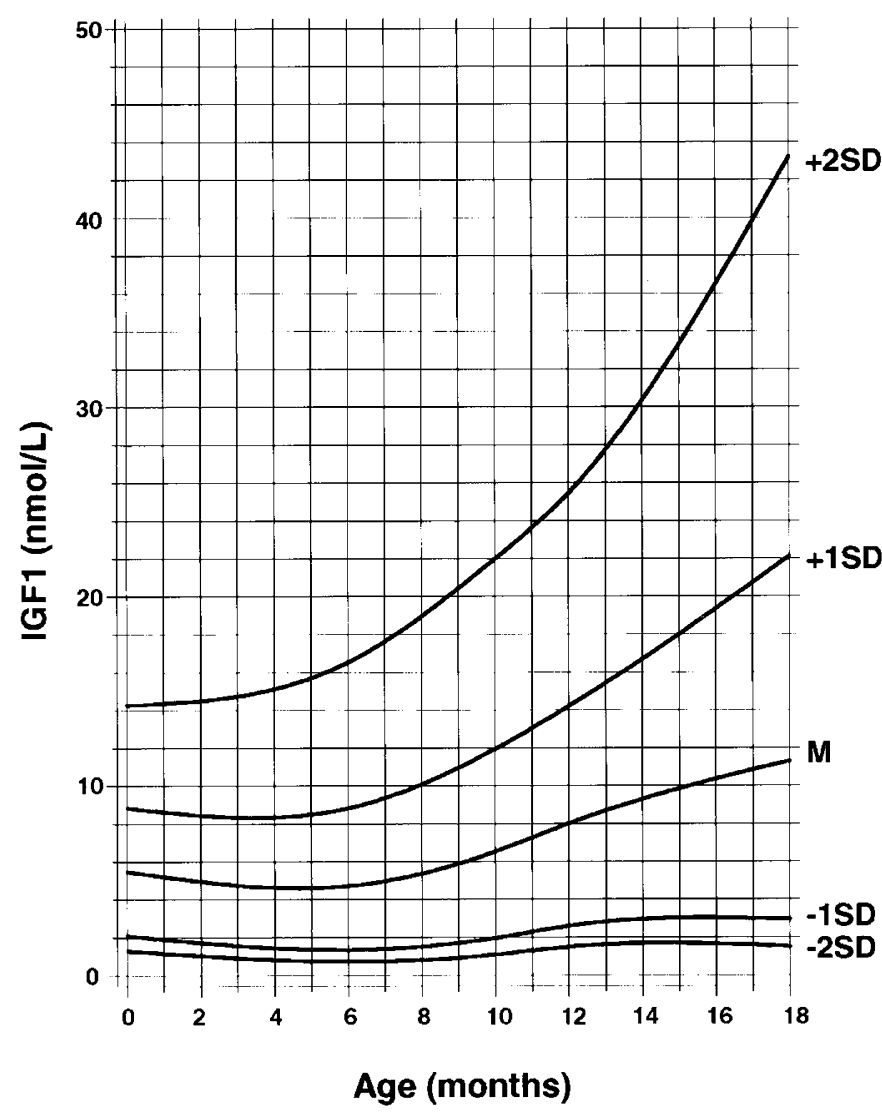

Figure 1. Serum IGF-I concentrations from birth to 18 mo based on the pooled longitudinal data of 25 boys and 23 girls. Reference values correspond to the antilogarithm of the mean (M) and 1 and 2 SDs about the mean.

lation was found between the change in growth factors and change in length and BMI at other periods of the study.

The 34 infants with onset of childhood phase of growth between 6 and 10 mo had a higher mean serum IGF-I value at $10 \mathrm{mo}(8.8 \pm 5.8 \mathrm{nM}$ versus $4.9 \pm 3.1 \mathrm{nM}, p<0.05)$ and higher length velocity between 10 and $12 \mathrm{mo}(16.3 \pm 4.7 \mathrm{~cm} / \mathrm{y}$ versus $8.8 \pm 4.3 \mathrm{~cm} / \mathrm{y}, p<0.001)$ compared with the 14 infants with a later onset after 10 mo of age (Fig. 4). There was no significant difference in the serum IGFBP-3 and GHBP levels between the two groups. No correlation was found in these measurements between birth and 6 mo and between 12 and 18 mo. A significant correlation between a change in serum IGF-I and a change in serum IGFBP-3 levels was observed during the three 6-mo periods between birth and $18 \mathrm{mo}$, but a significant correlation between a change in serum GHBP and a change in serum IGF-I or IGFBP-3 levels was only seen between 12 and 18 mo of age (Fig. 5). Table 3 shows the multiple regression model for length velocity between 6 and 12 mo against the variables observed during the same period $\left(r^{2}=0.43, p=\right.$ $0.0002)$. The change in serum GHBP and IGF-I concentrations between 6 and 12 mo of age and the age of onset of childhood phase of growth could explain $43 \%$ of the length gain between 6 and 12 mo of age in our babies.

\section{DISCUSSION}

The growth velocity during infancy is the highest during the growth process from birth to mature height. In early infancy,
GH levels are high whereas circulating IGF-I and IGFBP-3 concentrations are low relative to older children and adults (3, $8-10)$. The high circulating GH levels in infancy may be the result of a lack of negative feedback from the relatively low concentrations of circulating IGF-I and low levels of $\mathrm{GH}$ receptors in tissues of infants, suggesting a degree of $\mathrm{GH}$ resistance (11-13). IGF-I is an important factor of embryonic and fetal differentiation and growth, and there is evidence that insulin rather than $\mathrm{GH}$ is the important determinant in fetal IGF-I production $(1,28)$. However, in recent animal studies, fetal IGF-I levels have been found to be significantly lower in GH-deficient fetuses than in those with normal GH levels, suggesting a minor role for $\mathrm{GH}$ in the regulation of fetal IGF-I and their binding proteins (29). Growth-retarded newborn infants have been shown to have higher serum $\mathrm{GH}$ and lower IGF-I concentrations $(9,30)$. In human fetuses throughout the second half of gestation, serum levels of IGF-I and IGFBP-3 concentrations have been found to be significantly inversely correlated to serum levels of GH, implying that fetal IGF-I and IGFBP-3 control could be influenced by pituitary GH secretion in addition to the predominant nutritional influence on these growth factors (30). During early neonatal life, serum IGF-I levels continue to be nutritionally dependent because an increase in serum IGF-I levels in the first 3 mo of life has been found to be associated with weight gain and hence increased nutrient intake after intrauterine nutrient deprivation (24). Even in children and adults, circulating IGF-I concentrations are significantly influenced by nutrient and caloric intake, falling with food restriction and rising on refeeding (31). We found a positive correlation between the change in serum IGF-I and length gain and change in BMI in the normal infants in our study during the first 6 mo of life. BMI change is a wellrecognized index of nutritional status. This finding supports the suggestion that nutrition is one of the most important regulators of serum IGF-I concentrations in early infancy. A clear rise in serum insulin and pulsatile GH secretion had been observed after feeding in a group of appropriate-for-gestational-age neonates (3). In our study, we could not find any significant correlation of serum IGF-I and IGFBP-3 levels with caloric or protein intake. It is likely that the infants in our study were all well nourished.

Pulsatile GH secretion has been demonstrated in preterm and term newborn infants $(3,32)$. The pulse periodicity of $2.5-3 \mathrm{~h}$ is similar to that observed in older children and adults, but the pulse amplitudes are higher $(3,33)$. GHBP, which corresponds to the extracellular domain of the GHR, is generated in humans by proteolytic cleavage of the ectodomain of the membranebound GHR $(34,35)$. GHR and GHBP concentrations are very low in the fetus and neonate $(12,13,36,37)$ and rise rapidly during infancy and progressively slower in childhood and adolescence to stabilize in the late teens (12, 37-39). It has been suggested that circulating GHBP level may serve as a useful index of tissue GHR responsiveness in humans in whom direct receptor measurements are difficult, but recently reservations have been raised about its isolated measurement in the assessment of GHR responsiveness without additional detailed tests of the entire GH-IGF-I axis (35). After late infancy and early childhood, serum IGF-I and IGFBP-3 concentrations 
Table 2. Serum GHBP, IGF-I, and IGFBP-3 concentrations in 48 Chinese babies from birth to 18 mo*

\begin{tabular}{lccccc}
\hline & \multicolumn{4}{c}{ Age (mo) } \\
\cline { 2 - 5 } \multicolumn{1}{c}{ Variable } & 0 & 6 & 10 & 12 & 18 \\
\hline GHBP $(\mathrm{pM})$ & $259.8(142)$ & $586.6(171)$ & $630(171)$ & $676.9(184)$ & $728.8(188)$ \\
IGF-I $(\mathrm{nM})$ & $6.3(3.1)$ & $5.5(3.3)$ & $7.7(5.5)$ & $9.7(5.1)$ & $13.6(8.5)$ \\
IGFBP-3 $(\mathrm{nM})$ & $64.6(11.7)$ & $69.9(9.9)$ & $90.5(15.7)$ & $102.4(13.7)$ & $109.4(14)$ \\
\hline
\end{tabular}

* Values shown are mean (SD).

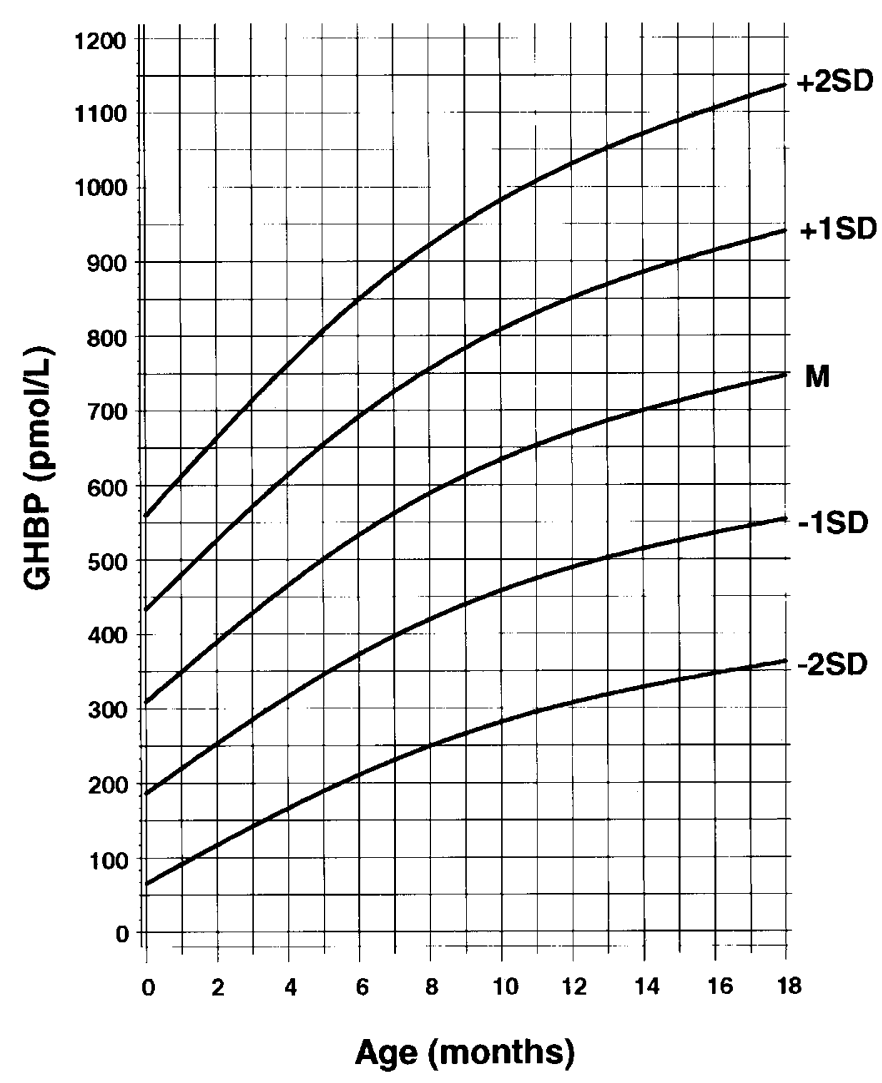

Figure 2. Serum GHBP concentrations from birth to 18 mo based on the pooled data of 5 boys and 23 girls. Reference values correspond to the mean (M) and 1 and 2 SDs about the mean.

become GH dependent. Serum IGF-I levels have been shown to correlate with endogenous GH secretion in pathologic and physiologic conditions (16). The serum GHBP levels had been found to correlate inversely with $24-\mathrm{h} \mathrm{GH}$ secretion in healthy boys of normal stature, and this reciprocal relationship between these two measurements was suggested as a reflection of the balance between $\mathrm{GH}$ production and $\mathrm{GH}$ action, which would be required to achieve the genetically programmed height (40). As frequent sampling for $\mathrm{GH}$ overnight or over $24 \mathrm{~h}$ is not practical in infants and young children, we decided to measure serum GHBP level in the infants of our study as an indicator of GHR responsiveness, despite the recent reservations (35), and serum IGF-I and IGFBP-3 as surrogate markers of GH action on growth, although admittedly IGF-I and IGFBP-3 could also be influenced by factors (e.g. age, nutrition, sex hormones) other than GH itself (16).

The mean age of onset of the childhood phase of growth in our cohort of normal Chinese infants was 9.9 mo for boys and 9.6 mo for girls, which was not significantly different from that derived from a Swedish longitudinal growth cohort (26). This

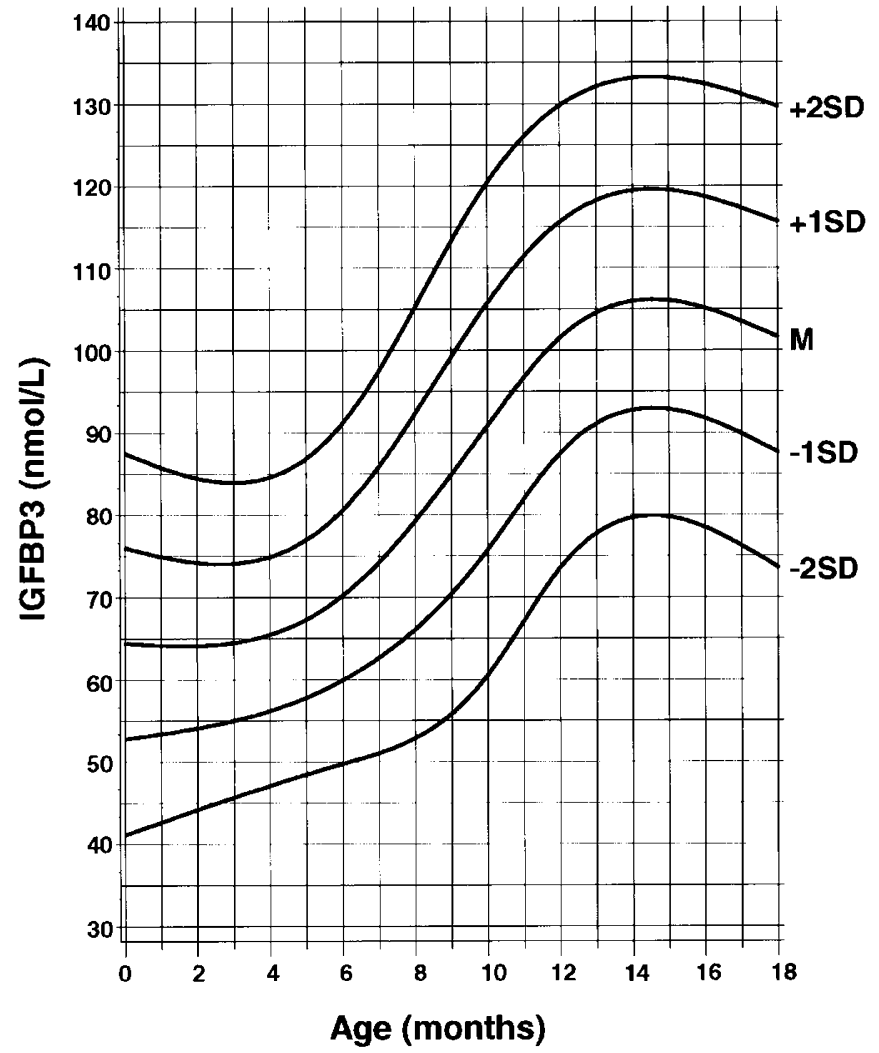

Figure 3. Serum IGFBP-3 concentrations from birth to 18 mo based on the pooled data of 25 boys and 23 girls. Reference values correspond to the mean (M) and 1 and 2 SDs about the mean.

suggests that growth faltering, which is commonly seen in developing countries (41), is no longer evident in present-day Chinese infants in Hong Kong, and this is the result of improvement in the socioeconomic status and health care in Hong Kong in the past 20 y (27). In our longitudinal study of serum GHBP, IGF-I, and IGFBP-3 concentrations in Chinese infants, there was a significant rise in serum GHBP by 6 mo of age with further rises at 10,12, and $18 \mathrm{mo}$. On the contrary, there was no significant rise in serum IGF-I and IGFBP-3 concentrations until 10 mo of age. We have also shown that the 34 infants with an onset of the childhood phase of growth before $10 \mathrm{mo}$ had a significantly higher mean serum IGF-I level at 10 mo of age and a greater length velocity between 10 and 12 mo of age compared with that observed in the 14 infants with the age of onset of the childhood phase of growth occurring after 10 mo of age. A significant association of the change in serum GHBP and the change in serum IGF-I or IGFBP-3 concentration was only demonstrated between 12 and 18 mo of age and not earlier, suggesting that the dependence of serum IGF-I and IGFBP-3 levels on GH does not take place until after the onset 


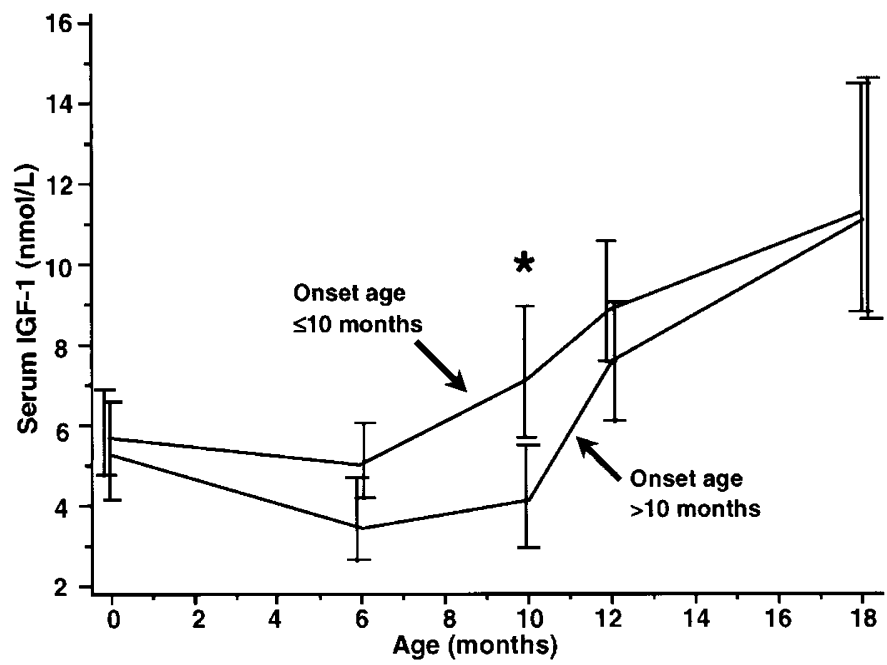

Figure 4. Serum IGF-I concentrations in the early and late-onset group with boys $(\mathrm{n}=25)$ and girls $(\mathrm{n}=23)$ combined $(* p<0.05)$.

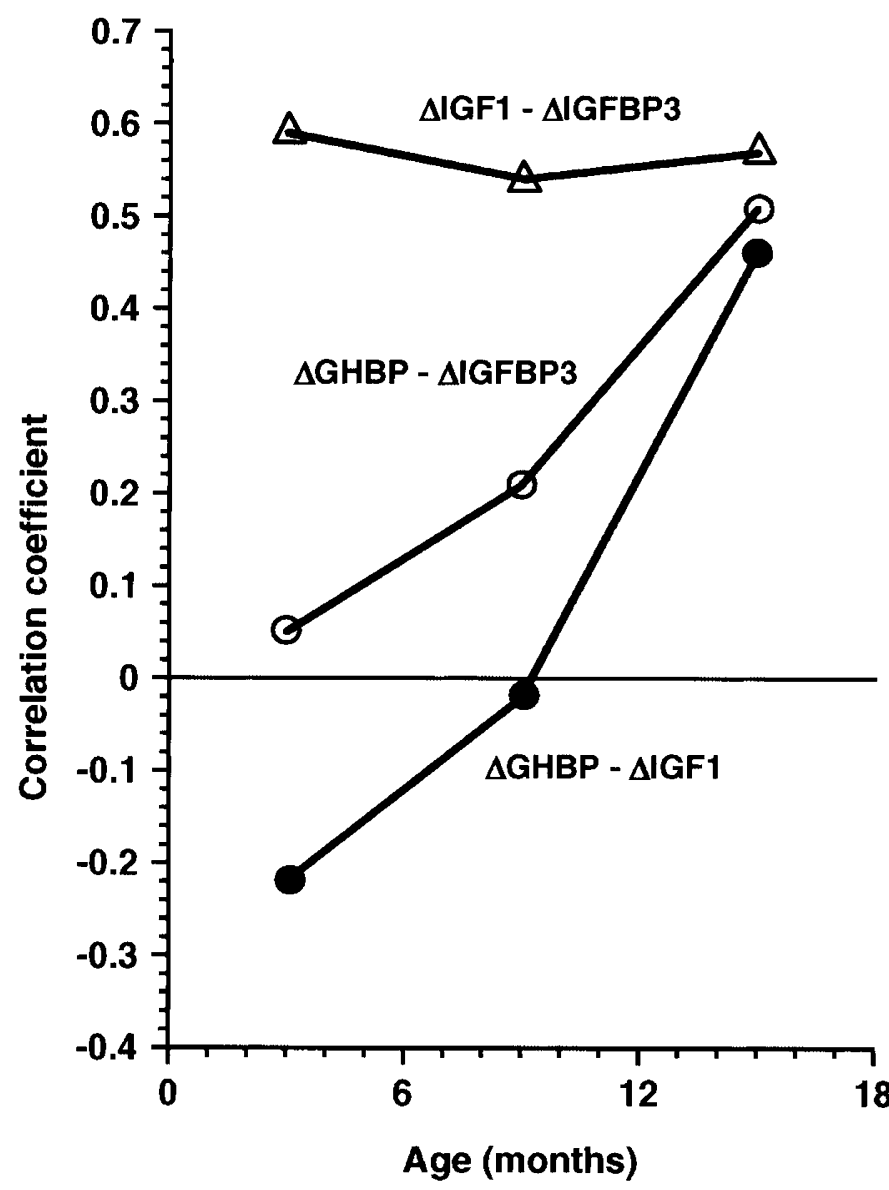

Figure 5. Bivariate correlation coefficients of the change in serum GHBP, IGF-I, and IGFBP- 3 concentrations between birth and $6 \mathrm{mo}, 6$ and $12 \mathrm{mo}$, and 12 and 18 mo of age. Boys $(n=25)$ and girls $(n=23)$ are combined.

of the childhood phase of growth in late infancy. The multiple regression analysis revealed that length velocity between 6 and 12 mo of age was significantly negatively associated with serum GHBP concentration and the age of onset of the childhood phase and positively associated with the serum IGF-I concentrations. Although these associations are not proof of a
Table 3. Multiple regression analysis for length velocity between 6 and 12 mo of age

\begin{tabular}{lccl}
\hline & \multicolumn{3}{c}{ Delta length $(6-12 \mathrm{mo})$} \\
\cline { 2 - 4 } \multicolumn{1}{c}{ Variable } & Slope & $t$ value & $p$ value \\
\hline Delta GHBP & -0.002 & -2.1 & 0.03 \\
Delta IGF-I & 0.12 & 2.8 & 0.007 \\
Delta IGFBP-3 & -0.025 & -1.65 & 0.107 \\
Sex & -0.57 & -1.78 & 0.083 \\
Onset age & -0.26 & -3.62 & 0.0008 \\
\hline
\end{tabular}

causal relationship, the results support our hypothesis that the onset of GH-dependent phase of growth occurs in late infancy and is associated with the onset of significant GH action on growth.

In this study we have established longitudinal reference data for serum GHBP, IGF-I, and IGFBP-3 concentrations in normal Chinese babies in the first 18 mo of life. There is an age-dependent increase in GHBP concentrations in early life with a significant increase evident by 6 mo of age, well before the significant increase in serum IGF-I and IGFBP-3 concentrations first noticeable at 10 mo of age. We have provided more detailed information on the changes of serum GHBP levels in early life than is presently available in the literature $(12,13,37,38,42)$. The serum IGF-I concentrations were not normally distributed, and there was a wide interindividual variation in the serum levels at the different times of the study (Fig. 1). The wide variability in the serum IGF-I concentration has been partially attributed to a genetic influence because it has been demonstrated that the within-pair correlation of serum IGF-I values for monozygotic twin pairs was significantly higher than that observed in dizygotic twin pairs of the same sex $(24,43)$. The marked variations in the serum concentrations of IGF-I in the first 18 mo of life will limit its usefulness in the assessment of growth disorder in early life. Contrary to our study, two previous studies reported little variation in the serum IGF-I concentration in the first $1-2$ y of life $(10,24)$. The reasons behind this difference in the reported developmental serum growth factors profile are not immediately apparent. Several studies have shown serum-free IGF-I measurements to be useful in the assessment of linear growth in childhood (17, $23,25,44)$. It is possible that serum-free IGF-I rather than total IGF-I level may be more sensitive to changes in GH secretory status and more useful in growth studies in infancy.

Significant correlation between serum IGF-I and IGFBP-3 concentration was demonstrated in infants from birth to $18 \mathrm{mo}$ of age, consistent with findings from previous studies $(10,24$, 30). A significant increase in serum IGFBP-3 concentration with age was noted in our babies, with a significant rise occurring first at 10 mo of age. Serum IGFBP-3 concentrations have also been found to be partially regulated by nutritional intake (22). A significant positive association between serum IGFBP-3 levels with BMI and sex has also been demonstrated in healthy infants (17) but no such correlation could be documented in our study cohort from birth to 18 mo of age. The lack of association of linear growth with a change in serum IGFBP-3 concentrations in our multiple regression analysis suggests that its measurement may not be as useful as serum 
IGF-I and GHBP in the assessment of growth in early life. The significant correlation between serum IGF-I and IGFBP-3 levels at different ages and the significant correlation of the change in IGF-I and the change in IGFBP-3 during the three 6-mo periods during the first 18 mo of life suggest that the changes in the concentrations of these two peptides are developmentally similarly regulated.

In summary, we have established reference data for serum GHBP, IGF-I, and IGFBP-3 concentrations in Chinese infants in early life. The results of our study support the hypothesis that the onset of the childhood phase of growth is associated with the onset of significant GH action on growth. The transition to GH dependence of serum IGF-I and IGFBP-3 concentrations takes place in late infancy.

Acknowledgment. The authors thank Ms. Jessica Cheng for her invaluable help in the preparation of the manuscript.

\section{REFERENCES}

1. Gluckman PD 1995 The endocrine regulation of fetal growth in late gestation: the role of insulin-like growth factors. J Clin Endocrinol Metab 80:1047-1050

2. Gluckman PD, Gunn AJ, Wray A, Cutfield WS, Chatelain PG, Guilbaud O, Ambler GR, Wilton P, Albertsson-Wikland K 1992 Congenital idiopathic growth hormone deficiency associated with prenatal and early postnatal growth failure: the International Board of the Kabi Pharmacia International Growth Study. J Pediatr 121:920923

3. Ogilvy-Stuart AL, Hands SJ, Adcock CJ, Holly JM, Matthews DR, Mohamed-Ali V, Yudkin JS, Wilkinson AR, Dunger DB 1998 Insulin, insulin-like growth factor I (IGF-I), IGF-binding protein I, growth hormone and feeding in the newborn. J Clin Endocrinol Metab 83:3550-3557

4. Baker J, Liu JP, Robertson EJ, Efstratiadis A 1993 Role of insulin-like growth factors in embryonic and postnatal growth. Cell 75:73-82

5. Woods KA, Camacho-Hubner C, Savage MO, Clark AJL 1996 Intrauterine growth retardation and postnatal growth failure associated with deletion of the insulin-like growth factor I gene. N Engl J Med 335:1363-1367

6. D'Ercole AJ, Hill DJ, Strain AJ, Underwood LE 1986 Tissue and plasma somatomedin-C/insulin-like growth factor I concentrations in the human fetus during the first half of gestation. Pediatr Res 20:253-255

7. Oliver MH, Harding JE, Breier BH, Gluckman PD 1996 Fetal insulin-like growth factor (IGF)-I and IGF-II are regulated differently by glucose or insulin in the sheep fetus. Reprod Fertil Dev 8:167-172

8. Adrian TE, Lucas A, Bloom SR, Aynsley-Green A 1983 Growth hormone response to feeding in term and preterm neonates. Acta Paediatr Scand 72:251-254

9. Deiber M, Chatelain P, Naville D, Putet G, Salle B 1989 Functional hypersomatotropism in small for gestational age (SGA) newborn infants. J Clin Endocrinol Metab 68:232-234

10. Rajaram S, Carlson SE, Koo WWK, Rangachari A, Kelly DP 1995 Insulin-like growth factor (IGF)-I and IGF-binding protein 3 during the first year in term and preterm infants. Pediatr Res 37:581-585

11. Breier BH, Ambler GR, Sauerwein H, Surus A, Gluckman PD 1994 The induction of hepatic somatotrophic receptors after birth in sheep is dependent on parturitionassociated mechanisms. J Endocrinol 41:101-108

12. Daughaday WH, Trivedi B, Andrews BA 1987 The ontogeny of serum GH binding protein in man: a possible indicator of hepatic GH receptor development. J Clin Endocrinol Metab 65:1072-1074

13. Bernardini S, Spadoni GL, Povoa G, Boscherini B, Hall K 1992 Plasma levels of insulin-like growth factor binding protein-I, and growth hormone binding protein activity from birth to the third month of life. Acta Endocrinol 127:313-318

14. Karlberg J 1987 On the modelling of human growth. Stat Med 6:185-192

15. Furlanetto RW, Underwood LE, Van Wyk JJ, D'Ercole AJ 1977 Estimation of somatomedin $\mathrm{C}$ levels in normals and patients with pituitary disease by radioimmunoassay. J Clin Invest 60:648-657

16. Le Roith D 1997 Insulin-like growth factors. N Engl J Med 336:633-640

17. Juul A, Holm K, Kastrup KW, Pedersen SA, Michaelsen KF, Scheike T, Rasmussen S, Muller J, Skakkebaek NE 1997 Free insulin-like growth factor I serum levels in 1430 healthy children and adults and its diagnostic value in patients suspected of growth hormone deficiency. J Clin Endocrinol Metab 82:2497-2502

18. Tato L, Du Caju M, Prevot C, Rappaport R 1975 Early variations of plasma somatomedin activity in the newborn. J Clin Endocrinol Metab 40:534-537
19. Sibergeld A, Litwin A, Bruchis S, Varsano I, Laron Z 1986 Insulin-like growth factor I (IGF-I) in healthy children, adolescents and adults as determined by a radioimmunoassay specific for synthetic 53-70 peptide region. Clin Endocrinol 25:67-74

20. Linehan JD, Smith RM, Dahlenburg GW, King RA, Haslan RR, Stuart MC, Faull L 1986 Circulating insulin like growth factor I levels in newborn premature and full-term infants followed longitudinally. Early Hum Dev 13:37-46

21. Kaplowitz PD, D'Ercole AJ, van Wyk JJ, Underwood LE 1982 Plasma somatomedin-C during the first year of life. J Pediatr 100:932-934

22. Barrios V, Argente J, Pozo J, Hervas F, Munoz MT, Sanchez JL, Hernandez M 1996 Insulin-like growth factor I, insulin-like growth factor binding proteins, and growth hormone binding protein in Spanish premature and full-term newborn. Horm Res 46:130-137

23. Hasegawa Y, Hasegawa T, Fujii K, Konii H, Anzo M, Aso T, Koto S, Takada M, Tsuchiya Y 1997 High ratio of free to total insulin-like growth factor I in early infancy. J Clin Endocrinol Metab 82:156-158

24. Leger J, Noel M, Limal JM, Czernichow P 1996 Growth factors and intrauterine growth retardation II. Serum growth hormone, insulin-like growth factor (IGF) I, and IGF-binding protein 3 levels in children with intrauterine growth retardation compared with normal control subjects: prospective study from birth to two years of age. Pediatr Res 40:101-107

25. Kawai N, Kanzaki S, Takano-Watou S, Tada C, Yamanaka Y, Miyata T, Oka M, Seino Y 1999 Serum free insulin-like growth factor I (IGF-I), total IGF-I and IGF-binding protein-3 concentrations in normal children and children with growth hormone deficiency. J Clin Endocrinol Metab 84:82-89

26. Liu YX, Albertsson-Wikland K, Karlberg J 2000 Long-term consequences of early linear growth retardation (stunting) in Swedish children. Pediatr Res 47:475-480

27. Tam SYM, Karlberg JPE, Kwan EYW, Tsang AMC, Baber FM, Low LCK 1999 The improvement in growth, socioeconomic and health status in Hong Kong Chinese infants: 1967 to 1994 . Hong Kong J Paediatr 4:3-9

28. Gluckman PD, Butler JH, Comline R, Fowden A 1987 The effects of pancreatectomy on the plasma concentrations of insulin-like growth factors-I and -2 in the sheep fetus. J Dev Physiol 9:79-88

29. Kim JD, Nanto-Salonen K, Szepankiewicz JR, Rosenfeld RG, Glassock GH 1993 Evidence for pituitary regulation of somatic growth, insulin-like growth factors I and 2 and their binding proteins in the fetal rat. Pediatr Res 33:144-151

30. Leger J, Oury JF, Noel M, Baron S, Benali K, Blot P, Czernichow P 1996 Growth factors and intrauterine growth retardation I. Serum growth hormone insulin-like growth factor (IGF)-I, IGF-II, and IGF binding protein 3 levels in normally grown and growth retarded human fetuses during the second half of gestation. Pediatr Res 40:94-100

31. Clemmons DR, Underwood LE 1991 Nutritional regulation of IGF-I and IGF binding proteins. Annu Rev Nutr 11:393-412

32. Miller JD, Esparza A, Wright NM, Garimella V, Lai J, Lester SE, Mosier Jr HD 1993 Spontaneous growth hormone release in term infants: changes during the first four days of life. J Clin Endocrinol Metab 76:1058-1062

33. Hindmarsh PC, Mathew DR, Brook CGD 1988 Growth hormone secretion in children determined by time series analysis. Clin Endocrinol 29:35-44

34. Sotiropolous A, Goujon L, Simonin G, Kelly PA, Postel-Vinay MC, Finidori J 1993 Evidence for generation of the growth hormone binding protein through proteolysis of the growth hormone membrane receptor. Endocrinology 132:1863-1865

35. Amit T, Youdim MBH, Hochberg Z 2000 Does serum growth hormone (GH) binding protein reflect human GH receptor function? J Clin Endocrinol Metab 85:927-932

36. Hill DJ, Freemark M, Strain AJ, Handwerger S, Milner RDG 1988 Placental lactogen and growth hormone receptors in human fetal tissues: relationship to fetal plasma human placental lactogen concentrations and fetal growth. J Clin Endocrinol Metab 66:1283-1290

37. Silbergeld A, Lazar L, Erster B, Keret R, Tepper R, Laron Z 1989 Serum growth hormone binding actively in healthy neonates, children and young adults: correlation with age height and weight. Clin Endocrinol 31:295-303

38. Holl RW, Snehotta R, Siegler B, Scherbaum W, Heinze E 1991 Binding protein for human growth hormone; effect of age and weight. Horm Res 35:190-197

39. Argente J, Barios V, Pozo J, Mumnoz MT, Hervas F, Stene M, Hernandez M 1993 Normative data for insulin-like growth factors (IGFs), IGF-binding proteins, and growth hormone-binding protein in a healthy Spanish pediatric population: age- and sex-related changes. J Clin Endocrinol Metab 77:1522-1528

40. Martha PM, Rogol AD, Blizzard RM, Shaw MA, Baumann G 1991 Growth hormonebinding protein activity is inversely related to 24-hour growth hormone release in normal boys. J Clin Endocrinol Metab 73:175-181

41. de Onis M, Monteiro C, Akre J, Glugston G 1995 The worldwide magnitude of protein energy malnutrition: an overview from the WHO Global Database on Child Growth. Bull World Health Organ 71:703-712

42. Tar A, Hocquette JF, Souberbielle JC, Clot JP, Brauner R, Postel-Vinay MC 1990 Evaluation of growth hormone binding proteins in human plasma using HPLC-gel filtration. J Clin Endocrinol Metab 70:680-686

43. Kao PC, Matheny AP, Lang CA 1994 Insulin-like growth factor I comparisons in healthy twin children. J Clin Endocrinol Metab 78:310-312

44. Heuck C, Skjaerbaek C, Orskov H, Wolthers OD 1999 Circadian variation in serum free ultrafiltrable insulin-like growth factor I concentrations in healthy children. Pediatr Res 45:733-736 